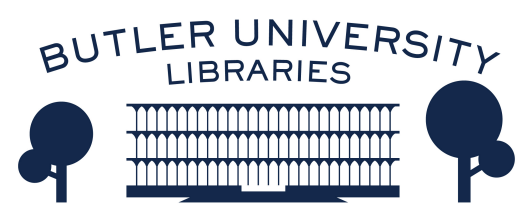

Journal of Hindu-Christian Studies

Volume 5

Article 4

January 1992

\title{
The Communion of Saints: Christian and Tamil Saiva Perspectives
}

S. Gangadaran

Israel Selvanayagam

Follow this and additional works at: https://digitalcommons.butler.edu/jhcs

Part of the Religion Commons

\section{Recommended Citation}

Gangadaran, S. and Selvanayagam, Israel (1992) "The Communion of Saints: Christian and Tamil Saiva Perspectives," Journal of Hindu-Christian Studies: Vol. 5, Article 4.

Available at: https://doi.org/10.7825/2164-6279.1057

The Journal of Hindu-Christian Studies is a publication of the Society for Hindu-Christian Studies. The digital version is made available by Digital Commons @ Butler University. For questions about the Journal or the Society, please contact cbauman@butler.edu. For more information about Digital Commons @ Butler University, please contact digitalscholarship@butler.edu. 


\title{
The Communion of Saints:
}

\section{Christian and Tamil Śaiva Perspectives}

\author{
S. Gangadaran* and Israel Selvanayagam ${ }^{* * *}$ \\ *Madurai Kamaraj University and Tamilnadu Theological Seminary \\ *** Tamilnadu Theological Seminary, Madurai
}

DISCUSSIONS ON SAINTS normally focus on the nature and meaning of sainthood. While apostels, church fathers, martyrs and people of outstanding dedication are considered as saints in Christian tradition, the Vedic sages and gurus are taken as counterparts in the Hindu religious tradition. ${ }^{1}$ But mostly significance is attached to their individual worth, charisma and exemplary life. However, the communion of saints is a significant phenomenon in the New Testament and its resemblance seems to lie more in the wandering saints of the regional bhakti traditions of Hinduism (C-500-700 CE) than in the Vedic sages and gurus. Particularly the theological significance attached to the communion of saints in the Tamil Śaiva scriptures is remarkable. Although the canonical leaders or teachers of Śaivism (nāyanārs) are well acknowledged for their devotional experience and their contribution to Śaiva Siddhanta, ${ }^{2}$ the theological significance of the communion of saints remains an undeveloped theme.

"I believe in the communion of saints" is part of the creeds used in the Christian tradition. This belief has both general and specific connotations. It has close association with the preceding belief in the holy catholic church occurring in the creeds. The idea of the communion of saints along with the community of Christians organized in the form of the Church has been seen as very unique in relation to, for example, the Hindu religious tradition. In India, it is no less than a person like P.D. Devanandan, one of the pioneers of the interfaith dialogue in this century who points out how "except perhaps in the more renascent move- ments, Hinduism has never thought in terms of congregational worship, where a corporate body of believers approaches God in a sense of togetherness and with the idea of seeking to know and do his will. The conception of the church is therefore a rock of offence to the Hindu believer?"3 Devanandan is right in his emphasis on church as a transforming community which is unique in Christianity. But his opinion of the absence of a corporate body of believers in traditional Hinduism needs to be questioned. Is there no sense of togetherness in approaching God to know and do his will in Hinduism? Is the concept of the Church really a rock of offence to the Hindu believer?

One of the fruits of inter-faith dialogue is the realization of important ideas which have been so far hidden in a faith tradition. The writers of this article, long time partners in the pilgrimage of Śaiva-Christian dialogue, realized at certain point that the phenomenon of the communion of saints found in the Tamil Saiva texts needs to be highlighted in the lgiht of what the Christian tradition has understood and made thematic concerning this notion. Although the Saiva communion of saints cannot be identified with the Christian Church, a study of its significance may help to recover it at least to a limited extent. This discovery in some way is important because the fact that Hinduism is an unorganized religion often appears to be a hindrance in the pursuit of inter-faith cooperation for social transformation. the following reflections are preliminary in nature which need to be developed further. We confine to the most important references to the communion of saints found in the New Testament and 
Journal of Hindu-Christian Studies, Vol. 5 [1992], Art. 4

14 S. Gangadaran and Israel Selvanayagam

in the twelve canonical books of Tamil Śaivism. The references are given as they appear without thematic classification. A summary at the end will highlight the fundamental aspects of communion of saints in Christian Tamil and Saiva traditions.

\section{"I believe in the Communion of Saints"}

The belief in communion of saints in the Christian Creeds was originally inserted to denote the unity of the living and the dead in the Church. In this connection in the Roman Catholic Church there was the practice to offer prayers to the dead canonized saints who were believed to be the mediators. But the reformers and the protestant church denounced this practice emphasizing that Christ alone was the mediator between God and the humankind. Today the communion of saints in most Christian traditions is taken to mean primarily the sacramental fellowship through baptism and the Eucharist. Secondarily, it is interpreted in terms of the unity of the Church as an instrument and model for the wider fellowship and unity (Koinonia) of the whole inhabited earth (Oikumene). It is difficult to point out the idea of communion of saints with doctrinal elements in the Bible. However, the relationship of God with a fellowship or community and His special presence in it is an important theme occurring in the Bible in relation to different aspects of the Christian faith. The following reference are taken as examples.

As a people the Istaelites were consecrated to God as a nation of priesthood and holiness (Ex. 19:5); so also were the Christians (1 Pet. 2:9). By partaking of God's holiness the creatures are called to be holy (Heb. 12:10). In this sense the Christians are called saints in the New Testament (2 Cor. 1:1). Being holy has the significance of spiritual relationship with God and moral character in life. More remarkably it implies that mutual santification too takes place in a family and in a Church (1 Cor. 7:14; Ephe. 5:22-33). According to the New Testament the Christian believers are united with Christ through baptism (Ro. 6:3f; Eph. 2:5f) and participate in the blood and body of Christ in Eucharist (Jn. 5:56; 1 Cor. 10:16); have fellowship with God through His Son Jesus Christ
(1 Cor. 1:9) and the Holy Spirit (Phil. 2:1; 2 Cor. 13:14); participate in the ministry to the 'saints' (fellow christians) (2 Cor. 8:4); and more significantly participate in Christ's sufferings (Phil. 3:10). They are built up as one body. The true Christians are so tightly united as to abide in the love of the Father and the Son, just as the Father and Son abide in one another and are only one (Jn. 14:20; 15:4,7; $17: 20,23 ; 1 \mathrm{Jn} .4: 12$ ). It is their privilege to have a share in the resources and fellowship of the Church and equally it is their responsibility to give a share for the common upliftment. The glorious future (1 The. 4:17; 1 Pet. 5:1) is given as a foretaste in the communion of saints.

Biblically speaking it is not enough to say that God is omnipresent. Of course, God's presence is unlimited. But he is actively present where people suffer politically, socially and economically as the history of Exodus amply shows. Further He is the God who moves about the dwellings of His people (2 Sam. 7:6). The temple was supposed to help realize God's presence in a community but it could never domesticate Him. The position of the early church in this regard could be seen not only in their gathering for worship in any place but also in that they emphasized the link between peoples' unity and God's favour as we read in Mt. 18:19. Following this verse Jesus says, "wherever two or three gather in my name I am in their midst." It is not out of place to recall that the risen Christ appeared to his disciplines when they were together and the Holy Spirit was poured down manifestly in the fellowship of believers. They are the living temples of the Spirit (1 Cor. 6:19). Therefore it is biblical to say that the sanctity of the Church lies in the unity of the people. This communion and unity is theologically significant in terms of God's active presence and His aim to create as united humanity using the communion of saints, i.e. the church as an instrument and model.

The Communion of Saints in the Tamil Saiva Tradition

Devotees as groups appear in the twelve canonical books of Tamil Śaivism. Here we see them in order of the books. Devotees (atiyavar) are those who have love in their heart. The 
Lord resides in the place of goodness and broadmindedness (Nallür Perumanam). In his Tevāram Jñāna Sambandar says that those who adore His feet and perform service will be rid of their suffering (entai inaiyati ettuvār, tun puru vārallar tontuceyvāre - p. 44). ${ }^{4}$

It is to be noted in this connection that saint Jñanna Sambandar gave release to all the devotees who came to his wedding at Nallūr Perumanam. By the grace of God, fire of knowledge appears and Jñāna Sambandar enters the fire of knowledge after all the devotees enter the fire with his newly wedded wife. ${ }^{5}$

Jñāna Sambandar in a verse ${ }^{6}$ describes Śiva's saving act of Mārkaṇ̣eyar from Yama, the lord of death. He observed that having known this fact, the representatives of Yama are afraid of coming near the devotees of the Lord.

The devotees engage in service contemplating Śiva as one who drank poison and having Uma as His consort. God prevents suffering for these devotees (p. 66). The devotees worship the feet of Siva for many days thinking that the Lord will redeem them and remove suffering for these devotees (p. 66). God is easily accessible to the devotees, but is not accessible to the celestials (p. 66f). Many singing devotees adore the dancing Lord with love (p. 67). The devotees who excel by their service praise the Lord with songs (p. 95).

Jñāna Sambandar is emphatic in his Tirukkallil decade that the devotees are not to be insulted on any account. This verse expresses the reverence with which the devotees are to be adored (p. 790). He says that the devotees who wear sacred ash, drink intoxicating drinks, the devotees of the Lord at Kallil are not to be insulted. Only ignorant people speak ill of the devotees. If the devotee wants knowledge and the consequent release, penance and consequent weakness of the body are not the way. The devotee has to worship the Lord at Tiruvalanjuli with the help of the hymns of Sambandar. In this way the devotee can attain knowledge and release (p. 544).

The devotees will not have diseases, will not be affected by wicked karmas, even the lord of death will leave the devotee and the supreme Lord gives the devotees refuge. They become devotees of the devotee of the Lord (p. 790).
Even heaven is not important for the devotees of the Lord who wear Konrai flower (p. 56). If one serves the devotee of the devotees, the spotless way of reaching God becomes easy ( $p$. 991). The devotees worship the Lord at Tiruppugalür with their songs, with flower, water and offerings and they always hear the praise of the Lord without interruption (p. 806). The ancient devotees of the Lord at Tiruppadiripuliyur break new ground and destroy old karmas (p. 1257). God is the light which transcends the light of the word. That God is to be found in the heart of the devotees (p. 727).

Appar, also known as Tirunāvukkarasar observes that good merit accrues to a person as a result of serving the devotees of a faultless devotee of the Lord (v. 5142). ${ }^{7}$ He also exhorts us to worship and serve the devotees of the Lord, to mingle with them and avoid those who do not serve the Lord (v. 5658).

Saint Sundarar calls God as "Lord, my father, the respectable Lord who has accepted me as His devotee for many (seven into seven i.e., forty nine) births.... Let me be the devotee of the devotees of the Lord" (v. 7762). He also observes: "I am your servant and you have complete control over me and I become your servant of my own accord" (v. 8789). It is remarkable that it was Sundarar who wrote the short hagiography of saints which was further elaborated by others. ${ }^{8}$

Mānikkavācakar's Tiruvācakam is the most popular devotional text of the Tamil Śaiva tradition forming the eighth of its twelve canonical books. The whole poem of Tiruvācakam centres. around the conversion experience of saint Mānikkavācakar that occurred quite unexpectedly when as a minister in the Pāndya Kingdom he on a trade trip met Siva in the form of a guru. Remarkably the guru was seated surrounded by a host of saints, and this scene transformed the poet to the core. $\mathrm{He}$ enjoyed the fellowship of these saints for a period forgetting his kingdom and trade. But when they were taken up he could not bear the feeling of separation and this he recalls repeatedly in his poem (e.g. 27.10). ${ }^{9}$ However, he had the opportunity of joining the fellowship of the Saiva saints in different places, particularly in Tillai (Citamparam), the centre of Tamil Śaiva tradition. It was here dwelling the 'all- 
glorious' company of Siva who gained grace to go with him and mingled in perfect union with himself (2.128-132). Māṇikkavăcakar's association with the communion of saints made him mention it in relation to God's special identification with them, the place of sakti, the consort of Siva in modelling this communion and to the experience of devotees here and hereafter.

Siva dances in the midst of his perfect saints (42.14). He rejoices amid those that fold adoring hands (1.9). Though he is supreme and transcendent with uncanny nature and capricious authority he is near to his servants $(6.86,87)$ from whom he never departs $(6.100)$. The praises of the devotees surround him $(1.94,95)$.

Mănikkavằcakar very strikingly sees the union of the goddess with Siva as an exemplary model. She is the chief servant who surrendered all her power to Śiva by marriage. Along with her Siva steps into the ancient huts (i.e. temples), so that their image may be a perpetual inspiration for the communion of saints (20.30; 5.291,292). They dwell within each other and in turn both dwell in saints. The following lines are graphic in this regard:

The Mistress dwells in midmost of Thyself; Within the Mistress centred dwellest Thou;

Midst of Thy servant if Ye Both do dwell, to me Thy servant over give the grace

Amidst Thy lowliest servants to abide.... (21.1-3).

Elsewhere the poet describes the joy of this multi-dimensional communion:

Here those who wash away their sin are gathered round;

This swelling tank is our Queen and King

We entering plunge and plunge again, our shells round;

Our anklets tinkling sound; our bosoms throb with joy;

The wave we plunge in swells, plunge into lotus crowned flood and joyful bathe.... $(7.50-52)$.

This song of maidens well represents the ecstatic fellowship of the saints who are united with Siva and the goddess, who is the paradigm for faithful devotion to and union with God.

The saints are the loving ones (anpar) who have gained cessation of all their bonds $(5.57 ; 32.21)$. They are the blessed ones (celvar) praising God always (1.95). Since Siva is united with them, their life is chiefly characterized by great freedom by his grace. Mānikkavācakar sings:

The King of all! He came, and made me, too, His own;

Henceforth I'm no one's vassal; none I fear!

We've reached the goal; with servants of His saints

In sea of bliss we evermore shall bathe. $(5.119,120)$

Like their supreme master the saints enjoy social freedom and spontaneity transcending the society of kin and caste. They sustain the life of each other always smiling, rejoicing and singing Śiva's sacred names (21.33-36).

Since Mānikkavācakar gained a new life in the midst of a host of saints, his association with the communion of saints helped him not only to keep the devotion dynamic but also to foresee his life after death with creative imagination. The poet is ever grateful to Siva for causing him to enter the band of devotees $(1.43 ; 6.106,107)$. The devotees he saw at the time of his conversion was a stimulating factor. Therefore, the saint asks Śiva to show once again the band of his devotees (21.32). Further, the fellowship in this world foreshadows a greater communion of saints in heaven where the "ancient saints" stand around the throne of Śiva (21.14). He prays:

The saints around thee, where Thou and they in happy sport commingled, ever dwell.

That I may thither rise to join the band,

Our only Bliss, in grace, $\mathrm{O}$ bid me come. $(21.27,28)$

Those who have gone ahead, Māṇikkavãcakkar says, have reached the Lord's grace and his feet $(32.59 ; 24.13,14)$. So he too hurries to be with them:

'Midmost of Thy devoted ones, like them in mystic dance to move;

Within thy home above to gain wish'd entrance, lo I eager haste!' $(5.41,42)$

Thus, for Mānikkavācakar, from the beginning up to the ultimate goal of his religious life the communion of saints provides a basic component of meaning of this life.

In the ninth Thirumurai we have a decade by Sundanar which is called Tiruppalläntu. The second song in this decade (290) ${ }^{10}$ describes: 
Those who have hard mind (not melting mind) do not come near the Lord; those who have melting mind and are real devotees come quickly. The devotees live by giving and receiving.

The devotees receive the grace from the Lord and give their body, belongings, and even their lives to Him. Here the term "giving and receiving" has a significant meaning. It primarily signifies giving his love to $\mathrm{Him}$ and receiving grace from Him. It also signifies giving and receiving the grace of God among the devotees. In this sense it shows the importance of the communion of saints and also shows the way in which the devotees of the Lord should live. The term "entering the temple as a group"-in this Tiruppallānu verse is also significant. The saints live as a group praising the grace of the Lord and the communion of saints is the expression of God's grace.

In the tenth book Tirumantiram we find a section called 'the praise of devotees'. The author makes a distinction between mobile God (the devotee) who is released from bondage and the immobile God who gives grace residing in temples. He says that if we give something to the immobile God in the temple, that will not reach the mobile God. But if we give something to the mobile God, it automatically reaches the immobile God, for God is the indwelling spirit behind all the devotees (1857). ${ }^{11}$

The eleventh Tirumurai is a collection of many poets and poetess. ${ }^{12}$ Kāraikal Ammaiyār who is the fore-runner of the bhakti movement representing the female saints talks about Siva and His devotees. She is one of the sixty three classical Nāyanārs of Saivism. She has sung with outpouring devotion. She says, "Oh! Ignorant mind! Consider always performing worships as your goal. Here performing worship is specifically referred to as worship of the devotees. She also advises us to be away from those persons who do not think of Śiva as a Person who has moon as His garland. Moon requests the pardon of Siva after expressing regret for his misdeeds. Śiva gives Moon the proper status by having him on His head like a garland. This shows that God gives His devotees pardon when they repent for their misdeeds.

Kāraikal Ammaiyār not only praises Śiva, but also emphasizes the importance of the devotees of Śiva by asking the devotees to desist from the company of persons who do not worship Siva with the Moon on His head. This is comparable to the twelfth sutra of the Sivajñāa Bodham, one of the fourteen philosophical texts of Śaiva Siddhanta, where Meykaṇdar asks us to wash the impurity of spiritual darkness (ānava mala) and to be with the company of devotees. The devotees should consider the faultless nature of Śiva's devotees and images which are in the temple giving grace to the devotees as Śiva Himself.

In the introduction (Päyiram) to the Tiruttonțar Purānam, the last book, Sekkilār talks about the assembly of Saints (punitar peravai - 4). ${ }^{13}$ The Śaiva devotees worship the Lord having the Moon on His head and sing His Praise. The assembly of the devotees enjoy the grace of the Lord through the songs of Śaiva leaders, i.e. the saints (Nāyanārs). Sekkilār praises the assembly of the holy people and prays to God for the success of the assembly of holy men in this world. He emphasizes the important characteristics of the devotees. He says that clinging on to the feet of Śiva who rides on the bull (standing for righteousness) the devotees renounce all attachment to the world (980).

So far we have glanced through the canonical books of Tamil Śaivism pointing out the significance of the communion of saints. Further we may consider the historical monuments of the corporate living of saints. The Devasiriyan Hall in the Tiruvarur temple is the historical monument which reminds us about the emergence of Tiruttonta togai by the initiative of Viranmenda Nāyanār. It is the practice in the Śaiva tradition to remember the saints particularly on their days of release and pay obeisance to them in veneration.

The mutts are the historical monuments of the corporate living of Śaiva saints and their service. Tirujñāna Sambandar Mutt at Madurai, for instance, brings to memory the saint who stayed in Madurai when he defeated the Jains in argument and established the supremacy of Saivism during the reign of Pandya King Nedumāran. There are literary indications about royal patronage extended to the saints in the Tamil country. 
Tiruppugalur Velakurichi Mutt is said to have been established by Appar when he stayed there along with devotee during his last days performing service in the temple. In Tiruperundurai temple we have a place where Siva came as a preceptor to guide Mānikkavãcakar for his spiritual enlightenment. Tillai or Cidambaram is the place where three thousand brahmins called Tillaivāl atanär (brahmins residing in Cidambaram) have the hereditary right of managing the Natarāja temple there. Even though we do not have three thousand priests now, we have more than three hundred priests who perform service in the temple.

It is remarkable that the communion of saints in the Tamil Śaiva tradition transcended caste and colour. Although a number of saints had the brahmanic background, once they joined the band of Saiva devotees, they stopped exercising any caste identity. We have a number of instances for brahmins receiving grace and blessing from the non-brahmin saints. The communion of saints provided an alternative to caste ridden society. However, one may wonder at the decline of the corporate spirit and social dimension exhibited by the communion of saints. Perhaps the penetration of brahmanic values such as the ãgamic ritual tradition and individual liberation contributed to the decline of the saints' movement. It is beyond the scope of this essay to investigate the reasons for this development, which is an important area for further study.

While the present day Śaivas celebrate the heritage of the saints, they do not feel compelled to recover the institution of the communion of saints. One reason may be the extraordinary catholicity of the pan-mythic Hindu faith to accommodate all living things and beings, from a blade of grass to a celestial God without bothering about a particular group. However, it should be recognized that a few attempts have been made to revive the spirit of corporate living of devotion and service to people. Kunțrakkuṭi Ațikal, for instance, started a forum called Deivikapperavai (Association of the Divine-oriented) and is working among the rural masses surrounding his mutt. Other śaiva mutts may also be inspired to follow suit. However, such developments continue to depend on the charisma of a few individuals like Kunțrakuți Ațikal. For more visible forums, therefore, it is left to the present Śaiva devotees and scholars to highlight and propagate the idea of the communion of saints.

\section{Conclusion}

It is not true to say that Hinduism is totally individualistic. While the brahmanic Hinduism developed a social stratification on the basis of caste, the bhakti traditions formed fellowship of saints around the image of God. The Tamil saiva tradition has a remarkable heritage of the communion of saints. Although they cannot be fully identified with the idea of the communion of saints in the Christian tradition, both have resembling theological significance.

Although God is present everywhere, $\mathrm{He}$ is actively present in the fellowship of His devotees as evident in the two traditions. God's grace and intimacy is closely related to this fellowship. The sacraments of baptism and Eucharist help the Christian saints to realize and celebrate this grace while the symbols of three horizontal lines on the forehead and holy ash on other parts of the body signify grace and liberation for the saiva saints. The saints in the formative period of the traditions become both models to be imitated and objects to be venerated (except in the protestant Christianity where veneration to saints is discouraged). Service is an important element in the communion of saints. It takes place within the fellowship and outside. But the major difference is that the Christian Church as the extension of saints and the body of saints in the sense of being forgiven and sanctified by God through the mediation and model of Jesus Christ has continued to exist in an organized form. But in the Saiva tradition there is no such continuity saving occasional fellowships and gatherings by the effort of charismatic individuals. However, it is always a possibility to recover the idea of the communion of Śaiva saints and to give it shape through the formation of fellowships and congregations not necessarily following the Christian Church model.

The communion of saints in the Christian tradition appears to have an universal appeal. It is often emphasized that the Church, despite 
all its pitfalls, must not only provide a model community of love, justice and unity but also be an instrument to achieve it. The Saiva saints also speak of Śiva as the God of all, and call all people for a liberated life and fellowship through His grace that $\mathrm{He}$ especially manifested through His devotees. But the unique Saiva voice is not often heard because of its integral place in the complex pan-mythic tradition of Hinduism. The idea of the communion of saints may prove to be a point of continuing dialogue between Christians and Śaivas.

\section{Footnotes}

1 See Robert L. Cohn, "Sainthood" in The Encyclopaedia of Religion, ed. Mircea Eliade, New York: Macmillan, 1987, Vol. 13, pp. 1-6.

2 See Indira Viswanathan Peterson, "Nāyanārs", Ibid., p. 13f. The bibliography given to this article gives an account of the most important materials available on this theme.

3 Robin Boyd, An Introduction to Indian Christian Theology, Madras; CLS, 1975, p. 198.

4 Moovar Tevāram; published by Kasi Tiruppanandal Mutt, 1968, p. 44. (As verse order is inconsistent we give the page no.)

5 Periyapurānam, 'Tirujñāna Sambandarpurāṇam,' 3155 and 3156 , published by Śaiva Siddhanta Maha Samajam, 1950. (Periyapuranam was written by Sekkilar giving the hagiography of saints).

6 Moovar Tevāram, p. 65.

7 Tevāram, Adankalmurai, published by Mayilai Ila Maruganar, 1953, Vol. II.

8 Sundarar is one of the leaders of Śaivism-(Nāyanār $)$ who composed the decade Tiruttonta togai which gives a short note of the sixty three devotees of Śaivism (63 individual devotees and nine groups of devotees like those who wear sacred ash, who praise devotees through devotion, who are born in Tiruvarur, etc.).

Nampiantar Nampi expands this decade into a work of 100 stanzas called Tiruttontar Tiruvantāti. Sekkilar expands this work into a grand epic of Śaivism (tiruttontar purānam, also known as Periyapurānam) consisting of 4287 stanzas. Sekkilar says that the reason for the emergence of Sundarar is to give Tiruttonta togai to our world.

Viranmindar, one of the 63 devotees was from Kerala. He wanted to renounce the world by clinging on to the feet of Siva and had concern for the devotee of Siva. When Sundarar want to worship Siva in the temple at Tiruvarur, he did not recognize the assembly of devotees in the Devaseriyan Hall at Tiruvarur temple. Viranmindar saw the failure of Sundarar in not recognizing the importance of devotees and considered Sundarar as "one of non-consequence" (puragu). Viranmindar thought that even though Sundarar himself was one of the leaders of Śaivism, his failure of not giving importance to the assembly of devotees can not be treated lightly.

It is interesting that Viranmindar considers even Śiva who gave importance to Sundarar who in turn did not recognize the importance of the assembly of devotees, as "one of non-consequence". After realizing the view of Viranmindar Sundarar paid respect to the assembly of devotees and then composed Tiruttonnta togai. Lord Siva helped Sundarar to start with the first line. "Tillaivāl antanartam ațiyārkkum ațiyär". (I am the devotee residing in Tillai).

Sekkilar describes the life history of Sundarar in the beginning, middle and end of Tiruttontar purānam and thus Sundarar is the hero of this epic.

9 Ref:: G.U. Pope, The Tiruvācagam or 'Sacred Utterances' of the Tamil Poet, saint and Sage Mānikkavācakar, Oxford: At the Clarendon Press, 1900. The first number in this section indicates the poem and the second the line).

10 Onpatäm (nineth) Tirumurai, pub. by Dharmapura Adheenam, 1969.

11 Tirumantiram, Pub. by Thiruvatuthurai Adheenan, 1987.

12 Patinorãm (Eleventh) Tirumurai, Pub. by Kasi Tiruppanandal Mutt, 1963, p. 20.

13 Periyapurātam, Madras: Śaiva Siddhanta Mahasamajam, 1950. Verse numbers given. 